Doc. JUDr. Mária Bujňáková, CSc., Faculty of Law, Pavol Jozef Šafárik University in Košice, Slovak Republic

\title{
PRINCIPLES AND PROBLEMS OF EVALUATION AND POPULARISATION OF SCIENTIFIC PUBLICATIONS IN SLOVAKIA
}

$\mathrm{T}$ The publications of scientific and pedagogical staff of universities are an important part of the evaluation of their performance in the field of scientific and professional activity, which would be reflected also in the pedagogical process. Publication activity reflects achieved work and its primary function is to acquaint a scientific community with results of research activities. Important communication channels are scientific and professional periodicals within the publications in a scientific academia. The publications are evaluated using qualitative, as well as quantitative methods. These quantitative methods and ways of evaluation of publications are mainly used when projects or grant applications are submitted, as well as at accreditations or qualification procedures of academics. On the other hand, it would be more important to examine the quality of results of academics in relation to the society and in relation to the improvement of the position of science as such.

The evaluation of the quality of individual periodicals is performed by several tools, or more precisely, by database products. These include products such as Thomson Reuters (Journal Citation Reports, Current Contents Connect, Web of Science) or the database SCOPUS from the Elsevier company. These databases are especially aimed at publications in English and it is necessary to note that these databases are not focusing on jurisprudence. And what is more, in Slovakia, there is no adequate tool serving to evaluate periodicals, through which articles published in domestic journals in the Slovak language could be evaluated. This is very decisive for law, which has a national character.

\section{Scientific and professional periodic publications}

The basis of the database of Slovak scientific and professional journals should be current periodic publications. Periodic publications are regularly issued publications of the same name, which are characterized by the complexity of the edition and by the continuity with previous and subsequent editions. It should be noted that at present in Slovakia there is no scientific journal in the field of law in which individual scientific outcomes could be published. This is often replaced by publishing either in Czech journal called Právnik or in the sporadically published journal Právny obzor, which really does not help jurisprudence. We consider that the area of tax law is in the specific situation and it is so for several reasons. Tax law as a separate branch of law is lectured and studied in Slovakia only at the Faculty of Law of UPJŠ. Others faculties of law lecture tax law within financial law and within grossly undersized credit subsidies, and this fact has a significant impact on the possibility of publishing in scientific journals.

On faculties of economic, respectively at universities where tax law is perceived under the category of economics, tax law has a slightly better position. In accordance with this, legal community cannot be satisfied and certainly we would make an effort to change this situation. The system of publishing journals, in which scientific results are presented, is very useful to economic sciences in Slovakia as well. As it was mentioned, in Slovakia there are no current journals in the area of jurisprudence, by which the scientific community of lawyers is truly impoverished. In the area of economics and management there is a relatively limited set of several hundred journals, in which the global leader in the field of quality assessing and indexing, Thomson Reuters, has ranked on its list of Current Contents Connect. Ekonomický časopis published by the SAV 
is among them in Slovakia, and in the Czech Republic, these areas are represented by journals Politická ekonómie and Finance a úver. This fact shows that it is necessary to do everything possible so that jurisprudence would have the journal that would be classified as current. Meanwhile, all efforts for the inclusion of such periodical were without results, mainly on the level of academics, since it is also a financial evaluation and it is generally known that universities and academia do not know how to influence this fact.

Whereas the list of current journals is very limited, it began to use the term "impacts" several years ago. This term refers to journals which are not current but which are included in other broader product of Thomson Reuters, which is called the Web of Science or in a competitive product, the Scopus. One Slovak peculiarity was removed by this (orientation only on "currents" was our regional speciality), on the other hand there was established the new one (in most of the world the Web of Science is only measure of the quality, not the Scopus). The aforementioned has significantly affected the possibility of publishing some scientific researches in the field of law. Again, it should be noted that economic sciences and the community of economics, which deals with taxes, reacted very quickly and have a tendency to rank among the recognized journals. It was noted that there are also efforts to predate publishing researches involving the area of taxes. While the Web of Science database is, with some exceptions, managed to maintain the quality, the Scopus contains a lot of journals for which the publishing is the only business. Practically anything is published in these journals, especially when the author pays and in this way should certainly not lead any scientific outcomes. It is important to mention, that these studies should not be accepted by the scientific community, though it is very complicated and may be even barely influenced.

From the point of view of information value of articles, there are different approaches to papers published in scientific periodical publications and to papers published in professional periodical publications. Articles with scientific nature are considered to be more significant due to the fact that they present new results of scientific researches. Scientific journals are periodical publications composed mainly of scientific articles presenting the newest, previously unpublished results of scientific research. Scientific papers published in scientific journals can be characterized as papers publicizing authentic thus original results of the author's own work. A scientific article as an essential element of scientific journals presents a scientific and educational unit, in which a written form reflects the new and original results of the scientific research.
Professional works represent the articles in professional journals that do not have scientific and exploratory character. However, the articles in these journals are characterized by high degree of professional processing of the issue by qualified author. The nonfiction style is used in these articles, by which verified professional and scientific knowledge is presented to the general public in an appropriate way.

One of the biggest distinction between a scientific journal and a professional journal is the type of information in the journal and the user perspective of a destination. Scientific information is characterized by originality and scientific character and professional information is defined by verifiability, applicability and intelligibility. Scientific articles, as a part of specific scientific discipline, are primarily intended to the scientific community. Published specific issues, the latest results of research, unpublished scientific information as yet, the use of scientific and educational style and exact terminology, all these reasons delimit the group of readers to a small community of scientists and specialists in the field. Unlike scientific articles, professional articles are written in more understandable style which is closer to the general public. It could be said that through the professional articles and journals scientific information and results of scientific research is mediated to the general public. In this context, we can deduce that in tax law, and of its enforcement, more often is used professional publication than scientific publication, especially from the known reasons of applicability of this information.

Scientific and professional journals are an irreplaceable informative channel not only in the scientific communication. Their common, scientific and professional value is reflected in the application of knowledge from these sources, not only in the future scientific research, but also in the ordinary life of their users. The very creation of the separate database of scientific and professional periodicals from the areas of law would bring several positives. From the international point of view, the aforementioned would be the mirror of the scientific and professional publishing in Slovakia.

\section{BIBLIOGRAPHY}

1. Kimlička Š., Spracovanie zoznamov publikačnej činnosti, ohlasov a aktivít, Stimul, 1998.

2. Kopecká M., UK Bratislava Filozofická fakulta 2012.

3. Edict of the Ministry of Education, Science, Research and Sport of the Slovak Republic no. 456/2012 Coll. 